\title{
Observations on the Pliocene sediments exposed at Antwerp International Airport (northern Belgium) constrain the stratigraphic position of the Broechem fauna
}

\author{
Frank P. WESSELINGH ${ }^{1,2, *}$, Freek S. BUSSCHERS ${ }^{3}$, Stijn GOOLAERTS ${ }^{4}$ \\ ${ }^{1}$ Naturalis Biodiversity Center, P.O. Box 9517, 2300 RA, Leiden, The Netherlands; frank.wesselingh@naturalis.nl. \\ ${ }^{2}$ Earth Sciences, Utrecht University, Utrecht, The Netherlands. \\ ${ }^{3}$ TNO - Geological Survey of the Netherlands, Princetonlaan 6, 3584 CB Utrecht, The Netherlands; freek.busschers@tno.nl. \\ ${ }^{4}$ OD Earth \& History of Life \& Scientific Heritage Service, Royal Belgian Institute of Natural Sciences, Belgium; \\ stijn.goolaerts@naturalsciences.be. \\ * corresponding author.
}

\begin{abstract}
Detailed observations at a large temporary outcrop south of Antwerp International Airport (northern Belgium) reveal the complexity of a thin interval of fossil-rich Pliocene sediments found on top of the upper Miocene Diest Formation. Based on the lithological characteristics and mollusc faunas, several units were tentatively attributed to the Kattendijk Formation and the Luchtbal and Oorderen Members of the Lillo Formation. Concretions containing characteristic preserved molluscs dominated by large paired bivalves and that are informally known as the Broechem nodules were observed in situ between the Kattendijk Formation and Lillo Formation, and in reworked position in the base of the latter, indicating a late Early Pliocene age. The role of extensive reworking in the formation of Pliocene units is shown and implications for stratigraphic framework of Pliocene deposits from northern Belgium are discussed.
\end{abstract}

KEYWORDS: Kattendijk Formation, Lillo Formation, Broechem nodules, mollusc faunas, taphonomy, stratigraphy, North Sea Basin, Zanclean, Piacenzian.

\section{Introduction}

The Antwerp harbour region (Belgium) is well known for its thick and fossil-rich Pliocene successions (e.g. Vervoenen, 1995; Marquet, 1998, 2002, 2004, 2005; Marquet et al., 2009; Duboys de Lavigerie et al., 2020; Tsai et al., 2020). To the east these units become thin and discontinuous and often are affected by decalcification and reworking and the stratigraphic subdivision is not well understood (Marquet, 1980; Bisconti \& Bosselaers, 2020; Bosselaers et al., 2004). To the southeast of Antwerp a Pliocene fauna has been documented that has a specific taphonomic character and species composition (Marquet, 1980; Wesselingh in van Bakel et al., 2003). This so-called Broechem fauna is found in brown-reddish spherical sandstone nodules of up to circa $15 \mathrm{~cm}$ long, and is dominated by single and paired specimens of a number of large bivalve species, partially as moulds, including Cyrtodaria angusta, Arctica islandica, Acanthocardia aff. aculeata, Cardiidae indet. (sensu Wesselingh in van Bakel et al., 2003) and Callista chione. The presence of Pygocardia rustica forma tumida implies an Early Pliocene age (Marquet, 1980; Wesselingh in van Bakel et al., 2003; Bosch \& Wesselingh, 2006). Marquet (1980) reported the Broechem fauna mostly ex situ from a gravel interval supposedly attributed to the Kattendijk Formation overlying upper Miocene Diest Formation deposits at temporary outcrops for the construction of a water basin between the villages of Broechem and Oelegem. However, the stratigraphic succession of the deposits overlying the Diest Formation from where Marquet reported the fauna remain poorly constrained.

In 2014, circa $10 \mathrm{~km}$ west of Broechem, two large temporary outcrops just south of Antwerp International Airport (AIA) for the construction of a tunnel located in the municipalities of Mortsel and Borsbeek (AIA LP1 \& AIA LP2; Fig. 1) exposed a fossiliferous Pliocene sequence on top of Miocene Diest Formation deposits (for the description of the latter, see Goolaerts et al., 2020, this volume) containing similar concretions allowing to better constrain the stratigraphic position of the Broechem fauna.

\section{Material and methods}

This paper is primarily based on field observations that are combined with a thorough study in the laboratory of samples collected from the Pliocene deposits exposed at AIA LP1 (southern entrance of the tunnel) and AIA LP2 (northern entrance of the tunnel) (Fig. 1). The field observations were gathered during three visits made by the authors in the summer of 2014 . At the time of the visits, Pliocene intervals were mostly located high in the outcrop walls (Figs 1,2) and only partially accessible at a working stair in LP1 and at places where excavations had not concluded in LP2. In addition, the Pliocene deposits were along major parts of the outcrop strongly distorted by Pleistocene cryoturbation (Fig. 2a). From four observation points labelled LP1-1, LP1-2, LP2-1 and LP2-2 (see Fig. 1), field observations are detailed and supplemented by photographs and schematized drawings of sections. Additional photographs of the section revealing the general build-up of the Pliocene sediments are incorporated in Goolaerts et al. (2020, this volume). A more extensive collection of photographs of AIA taken by SG was transferred to the Geology archives of the Royal Belgian Institute of Natural Sciences (RBINS) and can be consulted upon request. The Broechem fauna from AIA studied in this paper originates from sandstone concretions collected ex situ by Josine Voogt. Sediment samples from shell-rich layers (see Fig. 2) weighing $1.5-2.0 \mathrm{~kg}$ were selected for study and wet-sieved over a mesh size of $1 \mathrm{~mm}$. After sieving, the residues were dried prior to inspection and picking under stereomicroscope. For each sample, a lithological description was accompanied by a taphonomic and taxonomic assessment of the shells (following Marquet, 1998, 2002, 2005; Moerdijk et al., 2010; Pouwer, 2010) and shell fragments found in the residues, following criteria described in Cadée \& Wesselingh (2005). The unit descriptions below are based on a combination of field description and characterisation of the washed samples.

\section{Field observations}

\subsection{Observation point LP1-1}

The western outcrop wall (Figs 1, 2a) could only be observed from a distance. Overlying upper Miocene Diest Formation deposits (characterisation in Goolaerts et al., 2020) is a very strongly deformed shell-rich interval. The lower contact and internal architecture of the shelly interval shows deformation caused by cryoturbation. The basal c. $20-50 \mathrm{~cm}$ appear to be lighter grey coloured then surrounding units and matches characteristics of upper Pliocene deposits observed elsewhere in the AIA outcrop. At the base of this deformed shelly interval in one location a single brown, circa $10 \mathrm{~cm}$ diameter concretion was observed that confirms a Broechem type of concretion (see below). Shells fallen to the quarry floor consisted of mostly strongly worn Pliocene species but also some very well preserved freshwater species (Lymnaea, unionoid bivalve fragments). The latter likely derive from subrecent Quaternary deposits as medieval artefacts were also reported from these shelly deposits that contain reworked Pliocene material as well.

\subsection{Observation point LP1-2}

The LP1-2 is located at approximate coordinates $51^{\circ} 11^{\prime} 08.94$ ' $\mathrm{N}$, $4^{\circ} 28^{\prime} 18.93$ 'E, and shown in Figures 1, 2b. Here the section 
Figure 1. Google Earth Satellite view of the Antwerp International Airport site, with localization of the LP1 and LP2 pits and the four observation points referred to in the text.

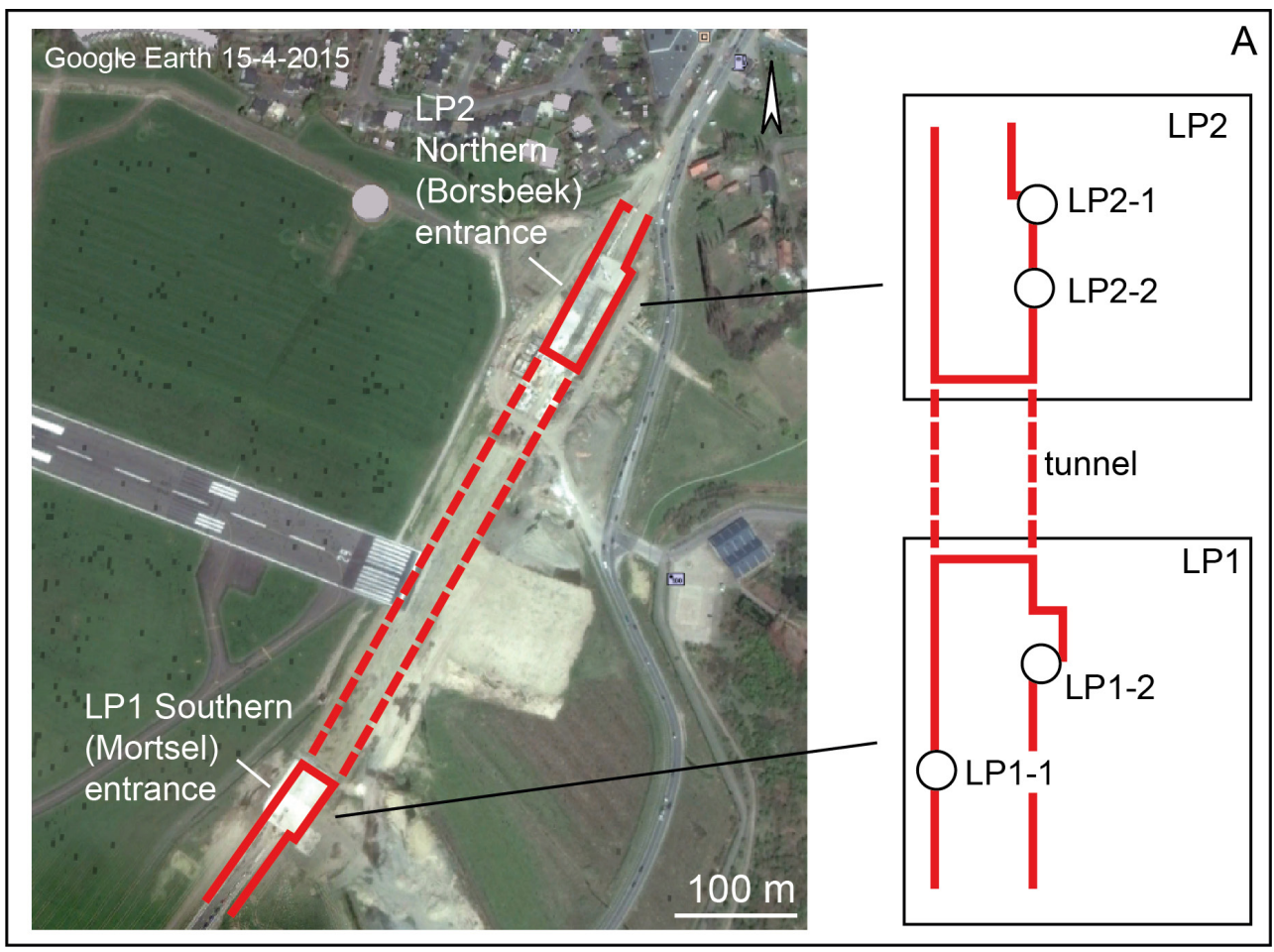

was visible at a temporary building stair, and in one place the actual wall was reachable for examination and sample collection (Sample BB01). The Pliocene succession overlays the Miocene Diest Formation (Fig. 2b) and has an undulating base and it could not be determined whether this was due to load casting, erosion or both. In some places an up to $15 \mathrm{~cm}$ thick dark brown-grey sterile sand layer (Unit 1 in Fig. 2b) was observed, overlain by a 40-50 $\mathrm{cm}$ thick dark green-grey to orange shell-rich glauconitic gravelly sand (Unit 2) that could be reached for sampling. Lithology and fauna (see below and Supplementary material) show that Unit 2 corresponds to the Kattendijk Formation. Overlying is a massive brownish 10-25 $\mathrm{cm}$ thick interval consisting of fine-grained sand with dispersed reddish-brown nodules of circa $10 \mathrm{~cm}$ (Unit $3)$. The nodules, as found on the floor of the outcrop, contain species, such as Callista chione, Acanthocardia aff. aculeata, Cardiidae indet. (sensu Wesselingh in van Bakel et al., 2003), Arctica islandica and Cyrtodaria angusta (Fig. 3b). The fauna and preservation is similar to the Broechem fauna as reported by Wesselingh in van Bakel et al. 2003 and Marquet, 1980. The top part of the exposure consists of grey very shell-rich sand with gravel. The upper unit is up to $80 \mathrm{~cm}$ thick, has a massively deformed base (due to loadcasting and/or cryoturbation). We are uncertain whether it concerns Pliocene Unit 5 or Quaternary Unit 6 with reworked Pliocene fossils as the interval was out of reach for sampling.

\subsection{Observation point LP2-1}

Outcrop LP2-1 is located in the NE outcrop wall (approximate coordinates $51^{\circ} 11^{\prime} 23.54^{\prime \prime} \mathrm{N}, 4^{\circ} 28^{\prime} 31.97$ 'E, Figs $1,2 \mathrm{c}$ ). In this part of the outcrop the most complete Pliocene succession was observed. Overlying the Diest Formation (Fig. 2c) irregular occurrences of brown to slightly reddish-brown fine-grained sand to silty sand containing nodules of c. $10 \mathrm{~cm}$ diameter were found (Unit 3). Maximum thickness is about $15 \mathrm{~cm}$ and this unit has the same properties as Unit 3 observed in outcrop LP1 and is therefore also attributed to the Broechem unit. It is overlain by $20-35 \mathrm{~cm}$ thick yellowish-grey shell layer (Unit 4). The sediment of Unit 4 is composed of mostly coarse grained quartz sand with few strongly reworked glauconite grains (as observed in the outcrop) and fine gravel composed of reworked phosphorite, flint, quartz and other lithoclasts. The fauna is dominated by horizontally stacked shells and fragments of Palliolum gerardi and Aequipecten opercularis (Supplementary material, Fig. 3c). The interval has lithological and faunistic characteristics (dominance of yellow-coloured Palliolum gerardi dominated faunas: De Meuter \& Laga, 1976) of the Luchtbal Member of the Lillo Formation. Inspection of the samples showed that the typical Luchtbal Member components all are comparative soft (surfaces are easily scratched and shells can disintegrate along layers) and abraded and that a rare betterpreserved greyish-coloured fauna may represent the actual fauna during deposition of this interval (Supplementary material). On top in total a c. $80 \mathrm{~cm}$ package containing medium-grained quartz sand with common fine gravel and abundant very worn shells (Unit 5) was observed. The package has a sharp base and contains two unconformable horizons, but samples (Supplementary material) indicate this to be a single unit. Again here a very small portion of the fauna was found to be well preserved and the far majority consisted of strongly reworked and abraded shells and shell fragments, even including some Eocene fossils. Based on the mollusc species, the lack of fresh glauconite and the overall nonyellow colour of the sediments and fossils, Unit 5 is attributed to the Oorderen Member of the Lillo Formation.

\subsection{Observation point LP2-2}

The eastern outcrop wall adjacent to the previous observation point (Fig. 2d) enabled us to study the lateral properties of the various units. The base of the Pliocene is regularly undulating typical of loadcasting as seen in the many outcrops of thicker Lillo Formation sequences in the Port of Antwerp area (e.g. Deckers et al., 2020, this volume). Unit 3 (Broechem unit) is thin and wedges out towards the south, and follows the undulating topography of the loadcast horizon. Unit 4 (Luchtbal Member) overlies directly the Diest Formation in the middle part of the outcrop and also wedges out towards the south. At the base of the unit reddish nodules of the Broechem unit were observed indicating extensive erosion before deposition of the Luchtbal Member. Unit 5 (Oorderen Member) can be traced along the entire outcrop wall.

\section{Characterisation of the units}

The age and stratigraphic attribution of the $10 \mathrm{~cm}$ thick basal brownish layer (Unit 1) seen in observation point LP1-2 below the Kattendijk Formation (Unit 2) is uncertain. The layer could not be sampled and from about $2 \mathrm{~m}$ distance it appeared to consist of fine- or medium-grained massive sand. Unit 1 overlays the relatively unweathered Diest Formation and could be part of the intensely weathered top of the Diest Formation that is seen in other parts of the outcrop.

The Kattendijk Formation (Unit 2) is only found in the southern LP1 outcrop (sample BB01, Supplementary material). It is 


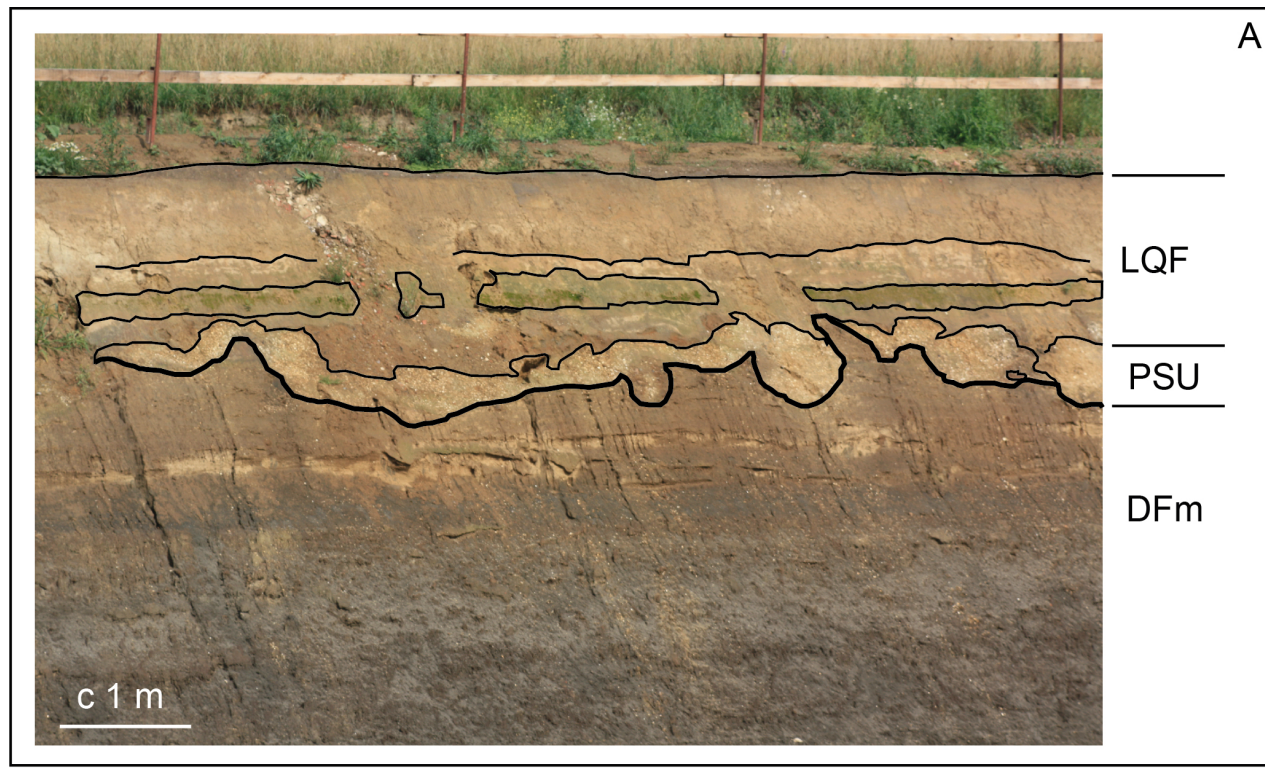

Figure 2. Observations at the Antwerp International Airport outcrop. Units and samples are discussed in text. (a) General view on observation point LP1-1. Pliocene fossiliferous sediments (PSU) being strongly deformed by cryoturbation occur on top of upper Miocene Diest Formation (DFm) and below Quaternary deposits (LQF). (b) Schematized succession at observation point LP1-2. (c) Schematized succession at observation point LP2-1. (d) Schematized layer structure at observation point LP2-2. F.s. - fine sand, m.s medium sand, c.s. - coarse sand, cgl. - gravel.
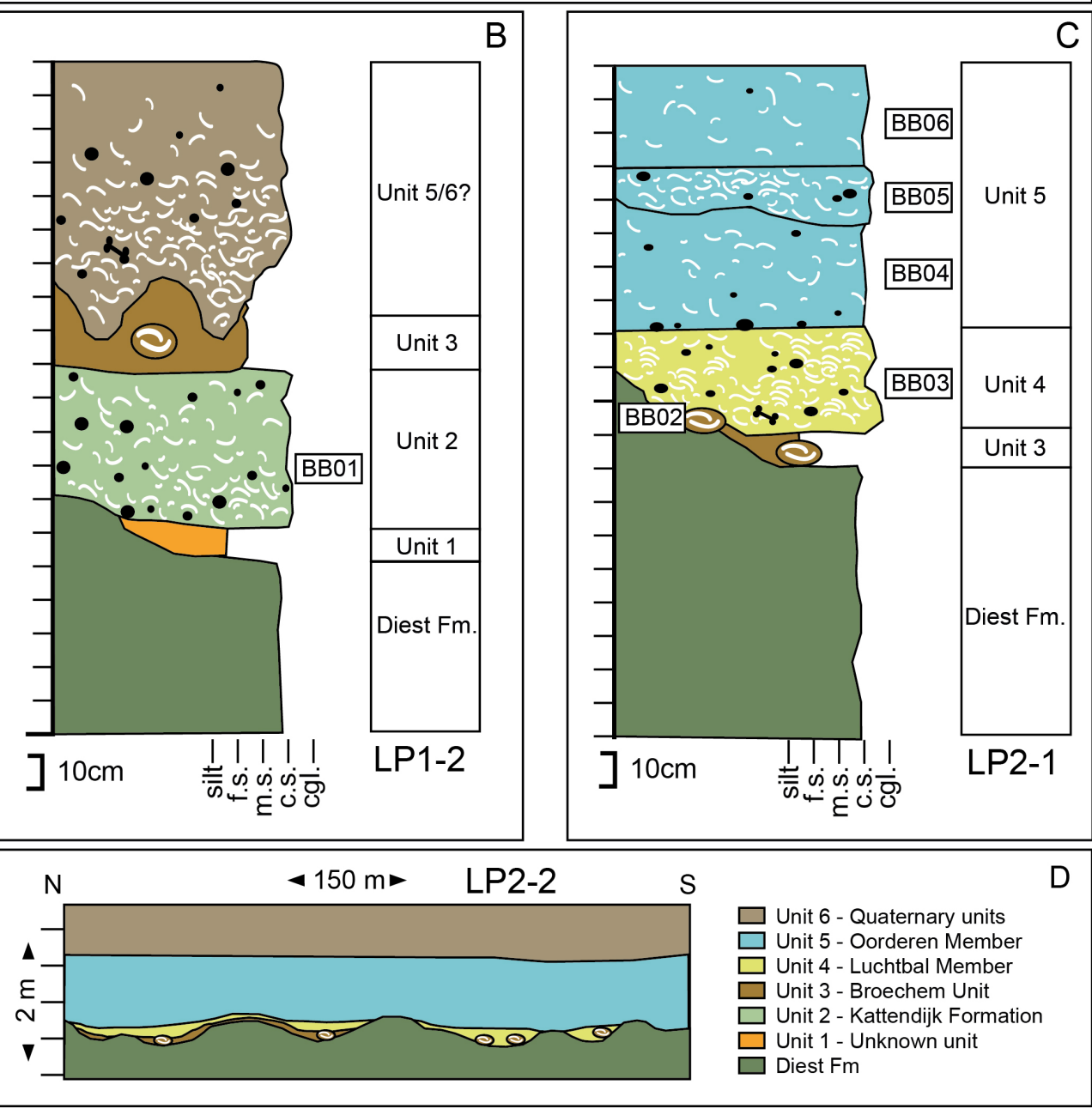

characterised by greenish-reddish coarse-grained sand and gravel with common shells and shell fragments (Fig. 3a) that all suffered from severe softening due to post-depositional dissolution. Much of the original glauconite is oxidised resulting in a reddish iron oxide coating on the shells. Bioerosion is common, yet some shells were preserved with fine surface details and the fauna as a whole has consistent warm-temperate fully marine species (Marquet, 2004; Moerdijk et al., 2010). The presence of Pygocardia rustica forma tumida and Turritella vanderfeeni are indicative of a Zanclean age (e.g. Bosch \& Wesselingh, 2006; see Table 1). Several species, such as Ostrea edulis and Digataria digataria, have not been reported from the Kattendijk Formation but are known from Early Pliocene units elsewhere in the southern North Sea Basin (Table 1). The occurrence of the two Pacific immigrant species Neptunea angulata and Mya sp. indicates that this layer corresponds to the upper part of the Kattendijk Formation as observed in the Deurgankdok construction pit (pers. obs. FPW) to the NW of Antwerp. Very similar faunal assemblages occur at the base of the Oosterhout Formation (B-Unit) at the Dutch locality of Langenboom that has a Zanclean age (Wijnker et al., 2008, table 1). The layer must postdate the first arrival of these Pacific immigrants at circa 4.7-4.8 Ma (Vervoenen et al., 2014).

The Broechem concretions (Fig. 3b, c, Sample BB02, Supplementary material) have been observed in situ within a thin $(<20 \mathrm{~cm})$ interval of reddish to light brown-grey fine-grained sandstone (Unit 3 ). Unit 3 is very thin and discontinuous, and incised by the overlying Lillo Formation. The few nodules collected from the outcrop floor contained in situ paired bivalves 

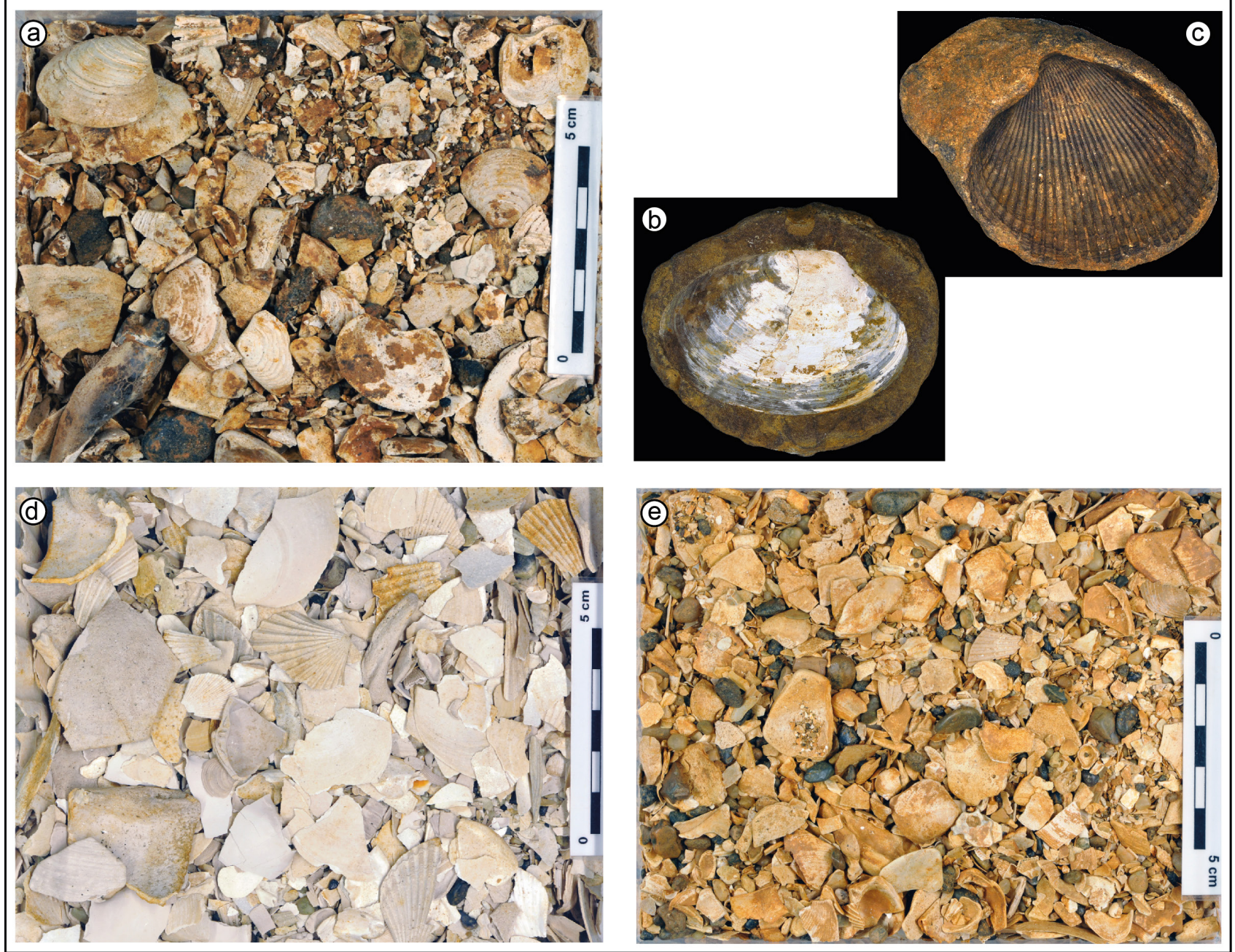

Figure 3. Impressions of faunal preservation of the different Pliocene units at AIA. (a) Sample BB01, Kattendijk Formation. (b) Sample BB02, RGM 926651, sandstone concretion with imprint of Cardiidae indet. (sensu Wesselingh in van Bakel et al., 2003). L nodule 114 mm. Leg/don. J. Voogt, LP2 locality. (c) Sample BBO2, RGM 926652, sandstone concretion with imprint of Callista chione (Linnaeus, 1758). L nodule 102 mm. Leg/don. J. Voogt, LP2 locality. (d) Sample BB03, Luchtbal Member, Lillo Formation. (e) Sample BB05, Oorderen Member, Lillo Formation.

that are variably but mostly strongly decalcified (Fig. 3b). The fauna in the AIA outcrop has the same characteristic species and preservation as the fauna published by Wesselingh (in van Bakel et al., 2003) and Marquet (1980). Characteristic taxa that were not or very rarely observed in the Pliocene of the southern North Sea Basin are Acanthocardia aff. aculeata, Cardiidae indet. (sensu Wesselingh in van Bakel et al., 2003, Fig. 3c) and Callista chione (Fig. 3b). The latter species is known from the Lower Pliocene Coralline Crag Formation of East Anglia (UK) and has been reported very rarely from the Kattendijk Formation and Luchtbal Member (Marquet, 2005). The general shape of Cardiidae indet. resembles Laevicardium decorticatum, but the species has far fewer, more pronounced and regular ribs giving some resemblance to Cerastoderma parkinsoni. The paired bivalves indicate in situ preservation in relative low energy settings and might indicate depths below storm wave base. The fauna as a whole lacks species characteristic for cold conditions and the presence of Callista chione (and Galeodea in Broechem: Marquet, 1980) is indicative of warm-temperate conditions (Moerdijk et al., 2010). The unit is truncated and partially removed by subsequent erosion as the heavy nodules are found at the base of overlying units. The Broechem unit lacks the abundant glauconite characteristic for the Kattendijk Formation and the lithology (fine-grained quartz arenite: Supplementary material) does not resemble any of the overlying Lillo Formation members. Further mapping and sedimentological analyses of this unit in the Antwerp-Campine area is necessary to assess whether the Broechem unit should be considered a bed, or might have a higher stratigraphic rank.

Material from the Luchtbal Member/Unit 4 (sample BB03, Supplementary material, Fig. 3d) contains two differentially preserved faunas in coarse-grained sand and gravel. The dominant fraction, making up possibly some $99 \%$ of the sample, is dominated by yellow to yellow-grey shells and fragments of mostly calcitic species (pectinids and oysters). A very small fraction (possibly about $1 \%$ ) consists of variable but usually wellpreserved grey shells and shell fragments. This relatively wellpreserved fauna is diverse (Supplementary material). Pygocardia rustica forma tumida and Scacchia oblonga are species known from the Luchtbal Member, Kattendijk Formation and the Lower Pliocene Coralline Crag Formation of the eastern UK (Table 1; Marquet, 2005; Moerdijk et al., 2010). Lentidium complanatum is known mainly from younger Piacenzian deposits in the Antwerp region (Marquet, 2004), but has been demonstrated from Lower Pliocene faunas from the eastern Netherlands (Peters \& Wesselingh, 2009). We are uncertain about the time lag between the reworked Luchtbal Member fraction and the grey faunal fraction in sample BB03. The latter does predate typical Piacenzian Oorderen Member faunas from the region (see below).

The Oorderen Member (Unit 5) samples (BB04-BB06, Supplementary material, Fig. 3e) all are dominated by strongly abraded shell fragments and only contain a very small fraction $(<1 \%)$ of finely preserved and thus presumably unreworked shells. The coarse-grained nature of the unit together with the dominance of strongly abraded shell fragments is indicative for high-energy settings. Very strongly worn Eocene Nummulites and Turritella solanderi occur, indicating regional fluvial input from areas to the south bringing in eroded Eocene deposits, likely during lowstands. There are no stratigraphically or ecologically incompatible species in the well-preserved fraction. The fauna contains species that are very common in the Oorderen Member of 


\begin{tabular}{|c|c|c|c|c|c|c|c|c|c|c|c|c|}
\hline & \multicolumn{4}{|c|}{ AIA } & \multicolumn{4}{|c|}{ AH } & \multirow{2}{*}{$\begin{array}{l}\mathrm{BR} \\
\mathrm{Br}\end{array}$} & \multirow{2}{*}{$\begin{array}{l}\text { EA } \\
\text { CC }\end{array}$} & \multirow[t]{2}{*}{ BA } & \multirow{2}{*}{$\begin{array}{l}\text { LA } \\
\text { UB }\end{array}$} \\
\hline & BB01 & BB02 & BB03 & BB04-06 & Ka & Lu & Oo & $\mathbf{K r}$ & & & & \\
\hline Ennucula laevigata (Sowerby, 1818) & & & $\mathrm{X}$ & & $\mathrm{X}$ & & $X$ & $\mathrm{X}$ & & $\mathrm{X}$ & $\mathrm{X}$ & $X$ \\
\hline Yoldia semistriata (Wood, 1840) & & & $\mathrm{X}$ & & $\mathrm{X}$ & $\mathrm{X}$ & $\mathrm{X}$ & & & $\mathrm{X}$ & $\mathrm{X}$ & $X$ \\
\hline Heteranomia squamula (Linné, 1758) & & & & $\mathrm{RX}$ & $\mathrm{X}$ & & $\mathrm{X}$ & $\mathrm{X}$ & & $\mathrm{X}$ & $\mathrm{X}$ & $\mathrm{X}$ \\
\hline Pecten grandis Sowerby, 1828 & & & $\mathrm{R}$ & & $\mathrm{X}$ & $\mathrm{X}$ & & & & $\mathrm{X}$ & & \\
\hline Aequipecten opercularis (Linné, 1758) & & & $\mathrm{R}$ & $\mathrm{R}$ & $\mathrm{X}$ & $\mathrm{X}$ & $\mathrm{X}$ & $\mathrm{X}$ & & $\mathrm{X}$ & $\mathrm{X}$ & $\mathrm{X}$ \\
\hline Aequipecten wagenaari Marquet \& Dijkstra, 2000 & & & $\mathrm{R}$ & & & $\mathrm{X}$ & $\mathrm{X}$ & & & $\mathrm{X}$ & & $\mathrm{X}$ \\
\hline Talochlamys harmeri (Van Regteren Altena, 1937) & & & & $\mathrm{R}$ & & & $\mathrm{X}$ & & & & & $\mathrm{X}$ \\
\hline Palliolum tigerinum (Möller, 1776) & & & & $\mathrm{R}$ & $\mathrm{X}$ & $\mathrm{X}$ & $\mathrm{X}$ & & & $\mathrm{X}$ & & $\mathrm{X}$ \\
\hline Palliolum gerardi (Nyst, 1835) & $\mathrm{X}$ & & $\mathrm{R}$ & $\mathrm{R}$ & $\mathrm{X}$ & $\mathrm{X}$ & & & & $\mathrm{X}$ & $\mathrm{X}$ & $\mathrm{X}$ \\
\hline Ostrea edulis (Linné, 1758) & $\mathrm{X}$ & & $\mathrm{R}$ & & & & $\mathrm{X}$ & $\mathrm{X}$ & & & $\mathrm{X}$ & $\mathrm{X}$ \\
\hline Cyclocardia scalaris (Sowerby, 1825) & $\mathrm{X}$ & & $\mathrm{X}$ & & & $\mathrm{X}$ & $\mathrm{X}$ & $\mathrm{X}$ & & $\mathrm{X}$ & $\mathrm{X}$ & $\mathrm{X}$ \\
\hline Astarte incerta Wood, 1853 & $\mathrm{X}$ & & $\mathrm{RX}$ & $\mathrm{RX}$ & & $\mathrm{X}$ & $\mathrm{X}$ & $\mathrm{X}$ & & $\mathrm{X}$ & $\mathrm{X}$ & $\mathrm{X}$ \\
\hline Digitariopsis obliquata obliquata (Sowerby, 1817) & $\mathrm{X}$ & & $\mathrm{R}$ & & & $\mathrm{X}$ & $\mathrm{X}$ & $\mathrm{X}$ & & & $\mathrm{X}$ & $\mathrm{X}$ \\
\hline Laevastarte basteroti (De la Jonkaire, 1823) & $\mathrm{X}$ & & $\mathrm{X}$ & & $\mathrm{X}$ & $\mathrm{X}$ & $\mathrm{X}$ & & & & & $\mathrm{X}$ \\
\hline Laevastarte ovatocostata Pouwer, 2010 & $\mathrm{X}$ & & $\mathrm{X}$ & & & $\mathrm{X}$ & $\mathrm{X}$ & & & & & \\
\hline Laevastarte omalii s.l. (De la Jonkaire, 1823) & $\mathrm{X}$ & & & & $\mathrm{X}$ & $\mathrm{X}$ & $\mathrm{R}$ & & & $\mathrm{X}$ & & $\mathrm{X}$ \\
\hline Laevastarte bipartita forma acuminata (Sowerby, 1826) & $\mathrm{X}$ & & & & & $\mathrm{X}$ & $\mathrm{R} ?$ & & & $\mathrm{X}$ & & \\
\hline Digitaria digitaria (Linné, 1758) & $\mathrm{X}$ & & & $\mathrm{X}$ & $X$ & $\mathrm{X}$ & $\mathrm{X}$ & $\mathrm{X}$ & & $\mathrm{X}$ & $\mathrm{X}$ & $X$ \\
\hline Digitaria forbesi (Wood, 1874) & & & $\mathrm{X}$ & & $\mathrm{X}$ & $\mathrm{X}$ & $\mathrm{X}$ & & & $\mathrm{X}$ & & \\
\hline Goodallia triangularis (Montagu, 1803) & & & $X$ & $\mathrm{X}$ & $\mathrm{X}$ & $\mathrm{X}$ & $\mathrm{X}$ & & & $\mathrm{X}$ & & $\mathrm{X}$ \\
\hline Hemilepton nitidum (Turton, 1822) & & & & $\mathrm{X}$ & & $\mathrm{X}$ & $\mathrm{X}$ & & & & & $\mathrm{X}$ \\
\hline Scacchia oblonga (Philippi, 1836) & & & $X$ & & & $\mathrm{X}$ & & & & $X$ & & \\
\hline Cyrtodaria angusta (Nyst \& Westendorp, 1839) & & $\mathrm{X}$ & & & $\mathrm{X}$ & $\mathrm{X}$ & $\mathrm{X}$ & $\mathrm{X}$ & $\mathrm{X}$ & $\mathrm{X}$ & & $\mathrm{X}$ \\
\hline Acanthocardia aff. aculeata (Linné, 1767) & & $\mathrm{X}$ & & & & & & & $\mathrm{X}$ & & & $?$ \\
\hline Cardiidae indet. sensu Van Bakel, 2003 & & $\mathrm{X}$ & & & & & & & $\mathrm{X}$ & & & \\
\hline Gastrana laminosa (Sowerby, 1827) & & & & $\mathrm{X}$ & $\mathrm{X}$ & $\mathrm{X}$ & $\mathrm{X}$ & $\mathrm{X}$ & & $\mathrm{X}$ & & $\mathrm{X}$ \\
\hline Spisula triangulata (Wood, 1857) & & & $\mathrm{X}$ & $\mathrm{X}$ & $\mathrm{X}$ & $\mathrm{X}$ & $\mathrm{X}$ & $\mathrm{X}$ & & $\mathrm{X}$ & & $X$ \\
\hline Mya arenaria lata Linné, 1758 & & & & $\mathrm{X}$ & & & & $\mathrm{X}$ & & & $X$ & $X$ \\
\hline Mya indet. & $\mathrm{X}$ & & & & & & & & & & & \\
\hline Varicorbula gibba (Olivi, 1792) & $\mathrm{X}$ & & $\mathrm{X}$ & $\mathrm{R}$ & $\mathrm{X}$ & $X$ & $\mathrm{X}$ & $\mathrm{X}$ & & $\mathrm{X}$ & $\mathrm{X}$ & $\mathrm{X}$ \\
\hline Lentidium complanatum (Sowerby, 1822) & & & $\mathrm{X}$ & & & & $\mathrm{X}$ & $\mathrm{X}$ & & $\mathrm{X}$ & $\mathrm{X}$ & $\mathrm{X}$ \\
\hline Arctica islandica (Linné, 1767) & $\mathrm{X}$ & $\mathrm{X}$ & $\mathrm{R}$ & & $\mathrm{X}$ & $\mathrm{X}$ & $\mathrm{X}$ & $\mathrm{X}$ & $\mathrm{X}$ & $\mathrm{X}$ & $\mathrm{X}$ & $\mathrm{X}$ \\
\hline Pygocardia rustica forma tumida (Nyst, 1836) & $\mathrm{X}$ & $\mathrm{X}$ & $\mathrm{RX}$ & & $\mathrm{X}$ & $\mathrm{X}$ & & & $\mathrm{X}$ & & $\mathrm{X}$ & $X$ \\
\hline Timoclea ovata (Pennant, 1777) & & & $\mathrm{X}$ & & $\mathrm{X}$ & $X$ & $\mathrm{X}$ & $X$ & & $X$ & & $\mathrm{X}$ \\
\hline Callista chione (Linné, 1758) & $\mathrm{X}$ & $X$ & & & & $\mathrm{X}$ & & & $X$ & $\mathrm{X}$ & & $\mathrm{X}$ \\
\hline Venerupis cf. senegalensis (Gmelin, 1791) & & & & $\mathrm{X}$ & & & & & & & & $\mathrm{X}$ \\
\hline Turritella vanderfeeni Brakman, 1937 & $\mathrm{X}$ & & & & $\mathrm{X}$ & & & & & & & $\mathrm{X}$ \\
\hline Turritella incrassata Sowerby, 1814 & $\mathrm{X}$ & & $\mathrm{RX}$ & $\mathrm{RX}$ & $\mathrm{X}$ & $\mathrm{X}$ & $\mathrm{X}$ & $\mathrm{X}$ & & $\mathrm{X}$ & $\mathrm{X}$ & $\mathrm{X}$ \\
\hline Turritella solanderi (Mayer Eymar, 1877)* & & & & $\mathrm{R}$ & & & & & & & & \\
\hline Epitonium clathratulum minutum (Sowerby, 1823) & & & & $\mathrm{X}$ & & $X$ & $\mathrm{X}$ & $X$ & & $X$ & & \\
\hline Cerithiopsis subulata (Wood, 1848) & & & & $\mathrm{X}$ & $\mathrm{X}$ & $\mathrm{X}$ & $\mathrm{X}$ & & & $\mathrm{X}$ & & \\
\hline ?Cingula inusitata (Beets, 1946) & & & $\mathrm{X}$ & $X$ & $X$ & $\mathrm{X}$ & $X$ & $\mathrm{X}$ & & & & $\mathrm{X}$ \\
\hline Tornus belgicus (Glibert, 1949) & & & $X$ & $X$ & & $X$ & $X$ & $\mathrm{X}$ & & $\mathrm{X}$ & & $\mathrm{X}$ \\
\hline Neptunea angulata s.l. Harmer, 1914 & $\mathrm{X}$ & & & & $X$ & $\mathrm{X}$ & $X$ & $\mathrm{X}$ & & & & $\mathrm{X}$ \\
\hline Amyclina labiosa (Sowerby, 1824) & & & & $X$ & & $X$ & $X$ & $\mathrm{X}$ & & $X$ & $\mathrm{X}$ & $\mathrm{X}$ \\
\hline Euroscaphella indet./lamberti (Sowerby, 1816) & $\mathrm{X}$ & & & & $X$ & $X$ & $\mathrm{X}$ & & $X$ & & & $X$ \\
\hline Limacina ?atlanta (Mörch, 1874) & & & $\mathrm{X}$ & & $\mathrm{X}$ & $\mathrm{X}$ & $\mathrm{X}$ & & & & & $\mathrm{X}$ \\
\hline Pyramidella cf. laeviuscula Wood, 1842 & & & & $\mathrm{X}$ & $\mathrm{X}$ & $\mathrm{X}$ & & & & $\mathrm{X}$ & & $\mathrm{X}$ \\
\hline Odostomia conoidea (Brocchi, 1814) & & & & $\mathrm{X}$ & $\mathrm{X}$ & $\mathrm{X}$ & $X$ & $X$ & & $\mathrm{X}$ & & $\mathrm{X}$ \\
\hline
\end{tabular}

Table 1. Stratigraphic occurrences of the mollusc species found in AIA samples BB01 to BB06. Abbreviations: AH: Antwerp Harbour area; Ka: Kattendijk Formation; Lu: Luchtbal Member; Oo: Oorderen Member; Kr: Kruisschans Member; BR/Br: Broechem faunas from Broechem/Oelegem; EA CC: Corraline Crag (Zanclean) of East Anglia; BA: Zanclean from Balgoy, The Netherlands; LA UB: late Zanclean B unit of the Langenboom, The Netherlands; X denotes mollusc occurrence, R denotes likely reworked material. * Turritella solanderi is an Eocene species. Data compiled from Long \& Zalasewiecz (2011), Marquet (2004), Marquet \& Landau (2006), Moerdijk et al. (2010), Peters \& Wesselingh (2009), Pouwer (2010), van Bakel et al. (2003), Wijnker et al. (2008) and www. wtkg.org (accession date 11-11-2020) for Langenboom. 
the Lillo Formation. Species typical for the younger Kruisschans (e.g. Yoldia heeringi, Cerastoderma parkinsoni) and Merksem Members (e.g. Spisula inaequilatera) were not found, indicating that the uppermost part of the shelly interval at AIA correlates to the Oorderen Member.

\section{Regional stratigraphic implications}

The Broechem fauna derives from a layer located between sediments attributable to the Zanclean Kattendijk Formation and the Upper Zanclean/Lower Piacenzian Luchtbal Member (Lillo Formation). Large Callista chione combined with Pygocardia rustica forma tumida are known from the Coralline Crag Formation of the eastern United Kingdom (e.g. Marquet, 2005 and references therein). The fauna found in the Broechem nodules is very distinct from the fauna known from any other currently formally defined Pliocene unit in Belgium. The interval requires further sedimentological characterisation and its areal distribution should be mapped in order to assess whether it can be defined as a formal unit and at what rank. The Broechem unit likely represents a highstand interval as it contains in situ paired bivalves (indicative of low energy, e.g. below fair weather wave base) and is positioned in between high-energy units with common reworking. The nodules reported by Marquet (1980) derive from a basal gravel and are probably similar as the nodules reworked in the Luchtbal Member in the tunnel construction outcrop.

Within the Luchtbal and Oorderen Members an admixture of preservation types indicates the massive reworking of faunas and sediments. The best-preserved faunas that likely represent in situ faunas, only make up about $1 \%$ of the samples. Massive sediment reworking is capable to blur distinct formation boundaries as was shown by Slupik et al. (2007) for the Oosterhout-Maassluis Formations boundary in the adjacent delta region of the Netherlands. Such extensive reworking may well explain other uncertain age estimates for Pliocene units in the Antwerp area (see e.g. Louwye et al., 2004; De Schepper \& Head, 2008; De Schepper et al., 2009; Vervoenen et al., 2014). Age estimates for the various Pliocene units are summarised in Figure 4. Further research including taphonomical assessment of faunas may further refine the true depositional ages of these units that are strongly influenced by natural reworking.

\section{Acknowledgements}

We thank Josine Voogt (Amsterdam) for donating her collected Broechem concretions, Ronald Pouwer (Naturalis Biodiversity Center, Leiden) for astartiid identifications and critical feedback on the manuscript, prof. Noel Vandenberghe (KU Leuven) for the opportunity to add this paper at a late stage to the Special Issue. Pieter Gurdebeke (UGent) and Robert Marquet provided very good suggestions that improved this manuscript. The authors are extremely grateful to Eddy De Neve of Blaton, Günther Vanden Bossche and Koen Thijs of Jan De Nul n.v. and Werner Nijs and Alain Cox of 'Agentschap Wegen en Verkeer' for granting access to the AIA temporary outcrop.
Figure 4. Stratigraphic framework of Pliocene units in the southern North Sea Basin and the position of the Broechem unit (adapted from Vervoenen et al., 2014 and Munsterman et al., 2020). Abbreviations: FO: first occurrence; Quartern.: Quaternary; Gelas.: Gelasian; Fm: Formation, Mbr: Member.

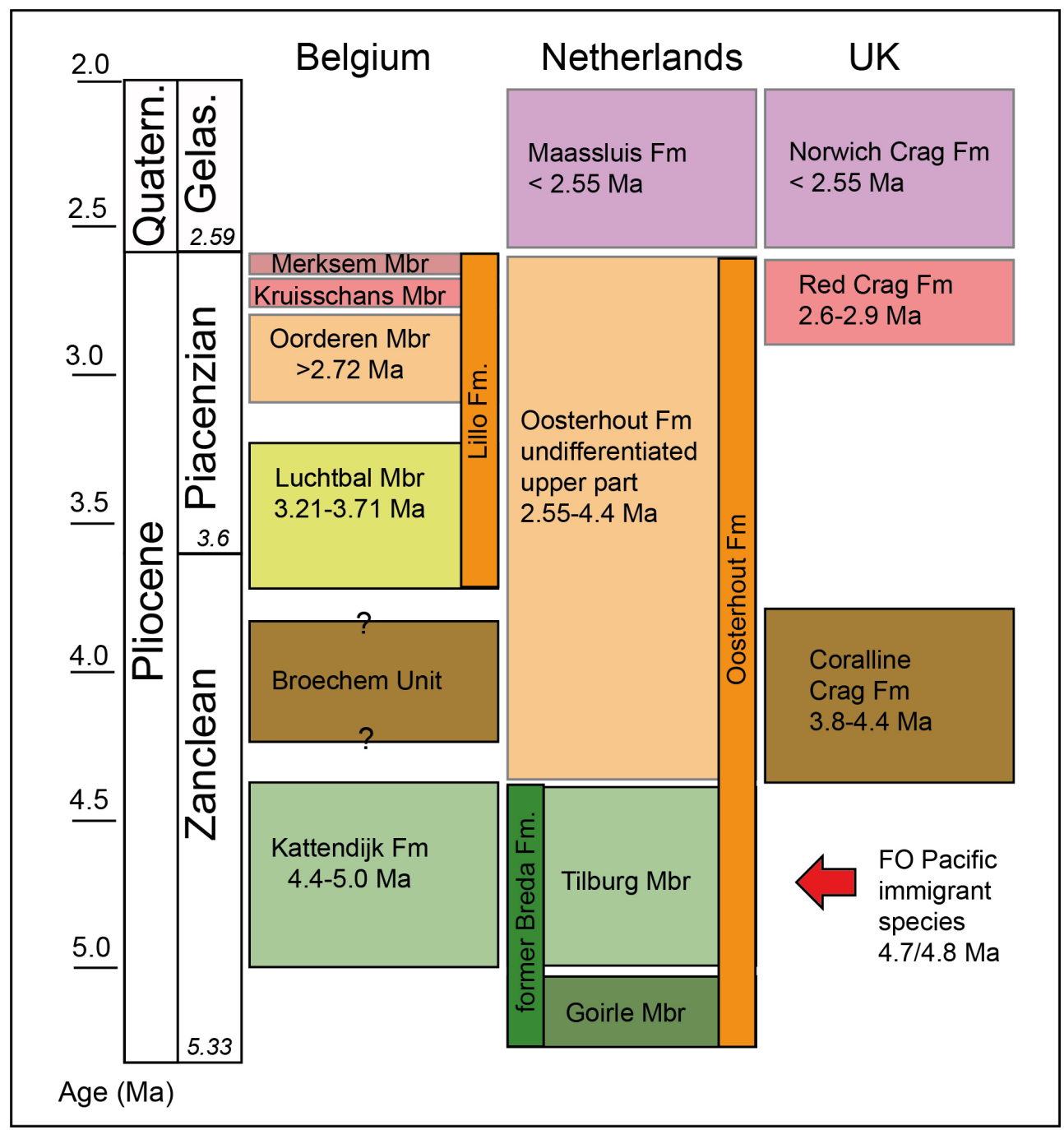




\section{References}

Bisconti, M. \& Bosselaers, M., 2020. A new balaenopterid species from the Southern North Sea Basin informs about phylogeny and taxonomy of Burtinopsis and Protororqualus (Cetacea, Mysticeti, Balaeonopteridae). PeerJ, 8:e9570. https://doi.org/10.7717/peerj.9570

Bosch, J. \& Wesselingh, F.P., 2006. On the stratigraphic position of the Delden Member (Breda Formation, Overijssel, the Netherlands) with implications for the taxonomy of Pygocardia (Mollusca, Bivalvia). Cainozoic Research, 4, 109-117.

Bosselaers, M., Herman, J., Hoedemakers, K., Lambert, O., Marquet, R. \& Wouters, K., 2004. Geology and palaeontology of a temporary exposure of the Late Miocene Deurne Sand Member in Antwerpen (N. Belgium). Geologica Belgica, 7/1-2, 27-39.

Cadée, G.C. \& Wesselingh, F.P., 2005. Van levend schelpdier naar fossiele schelp: tafonomie van Nederlandse strandschelpen. Spirula, $343,36-52$.

Deckers, J., Louwye, S. \& Goolaerts, S., 2020. The internal division of the Pliocene Lillo Formation: correlation between Cone Penetration Tests and lithostratigraphic type sections. Geologica Belgica, 23/3-4, this volume. https://doi.org/10.20341/gb.2020.027

De Meuter, F.J. \& Laga, P.G., 1976. Lithostratigraphy and biostratigraphy based on benthonic foraminifera of the Neogene deposits of northern Belgium. Bulletin de la Société belge de Géologie, 85/4, 133-152.

De Schepper, S. \& Head, M.J., 2008. New dinoflagellate cyst and acritarch taxa from the Pliocene and Pleistocene of the eastern North Atlantic (DSDP Site 610). Journal of Systematic Palaeontology, 6, 101-117. https://doi:10.1017/S1477201907002167

De Schepper, S., Head, M.J. \& Louwye, S., 2009. Pliocene dinoflagellate cyst stratigraphy, palaeoecology and sequence stratigraphy of the Tunnel-Canal Dock, Belgium. Geological Magazine, 146, 92-112. https://doi.org/10.1017/S0016756808005438

Duboys de Lavigerie, G., Bosselaers, M., Goolaerts, S., Park, T., Lambert, O. \& Marx, F.G., 2020. New Pliocene right whale from Belgium informs balaenid phylogeny and function. Journal of Systematic Palaeontology, 18/14, 1141-1166. https://doi.org/10.1080/1477201 9.2020.1746422

Goolaerts, S., De Ceuster, J., Mollen, F.H., Gijsen, B., Bosselaers, M., Lambert, O., Uchman, A., Van Herck, M., Adriaens, R., Houthuys, R., Louwye, S., Bruneel, Y., Elsen, J. \& Hoedemakers, K., 2020. The Upper Miocene Deurne Member of the Diest Formation revisited: unexpected results from the study of a large temporary outcrop near Antwerp International Airport, Belgium. Geologica Belgica, 23/3-4, this volume. https://doi.org/10.20341/gb.2020.011

Long, P.E. \& Zalasiewicz, J.A., 2011. The molluscan fauna of the Coralline Crag (Pliocene, Zanclean) at Raydon Hall, Suffolk, UK: Palaeoecological significance reassessed. Palaeogeography, Palaeoclimatology, Palaeoecology, 309, 53-72. https://doi. org/10.1016/j.palaeo.2011.05.039

Louwye, S., Head, M.J. \& De Schepper, S., 2004. Dinoflagellate cyst stratigraphy and palaeoecology of the Pliocene in northern Belgium, southern North Sea Basin. Geological Magazine, 141/3, 353-378. https://doi.org/10.1017/S0016756804009136

Marquet, R., 1980. De stratigrafie van Neogene afzettingen in een bouwput voor een water-reservoir te Broechem (prov. Antwerpen, Belgie). Mededelingen Werkgroep voor Tertiaire en Kwartaire Geologie, 17, 57-64.

Marquet, R., 1998. De Pliocene gastropodenfauna van Kallo (OostVlaanderen, België). Publicatie van de Belgische Vereniging voor Paleontologie vzw, 17, 246 p.

Marquet, R., 2002. The Neogene Amphineura and Bivalvia (Protobranchia and Pteriomorphia) from Kallo and Doel (Oost-Vlaanderen, Belgium). Palaeontos, 2, 1-100.

Marquet, R., 2004. Ecology and evolution of Pliocene bivalves from the Antwerp Basin. Bulletin de l'Institut royal des Sciences naturelles de Belgique, Sciences de la Terre, 74 supplément, 205-212.

Marquet, R., 2005. The Neogene Bivalvia (Heterodonta and Anomalodesmata) and Scaphopoda from Kallo and Doel (OostVlaanderen, Belgium). Palaeontos, 6, 1-142.

Marquet, R. \& Landau, B.M., 2006. The gastropod fauna of the Luchtbal Sand Member (Lillo Formation, Zanclean, Early Pliocene) of the Antwerp region (Belgium). Cainozoic Research, 5, 13-50.

Marquet, R., Collins, J., Jagt, J. \& van Bakel, B., 2009. The invertebrate fauna of the Pliocene in Belgium. Part I: Annelida, Anthozoa and Crustacea. Palaeofocus, 2, 41-61.
Moerdijk, P.W., Janssen, A.W., Wesselingh, F.P., Peeters, G.A., Pouwer, R., Van Nieulande, F.A.D., Janse, A.C., Van der Slik, L., Meijer, T., Rijken, R., Cadée, G.C., Hoeksema, D., Doeksen, G, Bastemeijer, A., Strack, H., Vervoenen, M. \& Ter Poorten, J.J., 2010. De fossiele schelpen van de Nederlandse kust. NCB Naturalis, Leiden, 332 p.

Munsterman, D.K., ten Veen, J.H., Menkovic, A., Deckers, J., Witmans, N., Verhaegen, J., Kerstholt-Boegehold, S.J., van de Ven, T. \& Busschers, F.S., 2020. An updated and revised stratigraphic framework for the Miocene and earliest Pliocene strata of the Roer Valley Graben and adjacent blocks. Netherlands Journal of Geosciences, 98, e8. https:// doi.org/10.1017/njg.2019.10

Peters, W.J.M. \& Wesselingh, F.P., 2009. Balgoy: een nieuwe Plioceen vindplaats voor Nederland met implicaties voor de Pliocene mollusken zonering van het Noordzeebekken. Afzettingen WTKG, $30,12-18$

Pouwer, R., 2010. The identity of Isocrassina, Laevastarte and Ashtarotha (Mollusca, Bivalvia, Astartidae) and their representatives from beaches and estuaries in The Netherlands and Pliocene strata in Belgium. Cainozoic Research, 7, 27-67.

Slupik, A.A., Wesselingh, F.P., Janse, A.C. \& Reumer, J.W.F., 2007. The stratigraphy of the Neogene-Quaternary succession in the southwest Netherlands from the Schelphoek borehole (42G4-11/42G0022) - a sequence-stratigraphic approach. Netherlands Journal of Geosciences / Geologie en Mijnbouw, 86/4, 317-332. https://doi. org/10.1017/S0016774600023556

Tsai, C.-H., Collareta, A. \& Bosselaers, M., 2020. A Pliocene Gray Whale (Eschrichtius sp.) from the eastern North Atlantic. Rivista Italiana di Paleontologia e Stratigrafia, 126, 189-196. https://doi. org/10.13130/2039-4942/13040

van Bakel, B.W.M., Jagt, J.W.M. \& Fraaije, R.H.B., 2003. A new Pliocene cancrid crab from Oelegem, province of Antwerpen (NW Belgium). Cainozoic Research, 2, 79-85.

Vervoenen, M., 1995. Taphonomy of some Cenozoic seabeds from the Flemish region, Belgium. Service Géologique de Belgique, Professional Paper, 272, 1-115.

Vervoenen, M., van Nieulande, F., Fraussen, K., Wesselingh, F.P. \& Pouwer, R. 2014. Pliocene to Quaternary sinistral Neptunea species (Mollusca, Gastropoda, Buccinidae) from the NE Atlantic. Cainozoic Research, 14, 17-34.

Wijnker, E., Bor, T.J., Wesselingh, F.P., Munsterman, D.K., Brinkhuis, H., Burger, A.W., Vonhof, H.B., Post, K., Hoedemakers, K., Janse, A.C. \& Taverne, N., 2008. Neogene stratigraphy of the Langenboom locality (Noord-Brabant, the Netherlands). Netherlands Journal of Geosciences, 87/2, 165-180. https://doi.org/10.1017/ S0016774600023209

Manuscript received 30.09.2020, accepted in revised form 16.11.2020, available online 12.12.2020.

Supplementary material is available online at https://doi. org/10.20341/gb.2020.026. 